\title{
ADSORPTION OF URANIUM SIMULATION WASTE USING BENTONITE:TITANIUM DIOXIDE
}

\author{
Kris Tri Basuki, Lutfi Aditya Hasnowo, Elza Jamayanti \\ Polytechnique Institute of Nuclear Technology \\ Sekolah Tinggi Teknologi Nuklir, Badan Tenaga Nuklir Nasional \\ Jalan Babarsari Kotak Pos 6101 YKBB Yogyakarta 55281 \\ kristri_basuki@batan.go.id
}

(Naskah diterima: 11-12-2018, Naskah direvisi: 25-01-2019, Naskah disetujui: 08-02-2019)

\begin{abstract}
ADSORPTION OF URANIUM SIMULATION WASTE USING BENTONITE:TANIUM DIOXIDE. Bentonite is a clay material of high surface area that have galleries within its structure. Bentonite that is modified with $\mathrm{TiO}_{2}$ will have high adsorption capability. In this study, natural bentonite and bentonite: $\mathrm{TiO}_{2}$ were characterized with FTIR, XRD and BET instruments to determine functional group, basal spacing, and specific surface area. This study also investigates the adsorption of bentonite: $\mathrm{TiO}_{2}$ in various environmental factors, such as $\mathrm{pH}(\mathrm{pH} \mathrm{1,3,5}$, and 8), contact time $(10,20$, $30,40,50,60,70,90$, and $120 \mathrm{~min}$ ), and initial uranium concentration (20, 40,60, $80 \mathrm{ppm})$, and their influences on adsorption capacity, and determine the kinetics equation and adsorption isotherm. Based on FTIR analysis, a decrease in the band of $\mathrm{O}-\mathrm{H}$ bond from water molecule was observed, which indicates the presence of $\mathrm{TiO}_{2}$ in bentonite interlayer structure. The XRD characterization of bentonite: $\mathrm{TiO}_{2}$ does not show diffraction peak in 001 plane. This is due to delamination of bentonite interlayer structure. Delamination is caused by the presence of $\mathrm{TiO}_{2}$ in large quantities, thus damaging the bentonite interlayer structure into irregular sheets. Bentonite as sheets will cause the basal spacing to increase and it is anticipated that XRD will find it difficult in detecting the 001 plane at a low 2 theta angle. The surface area of bentonite: $\mathrm{TiO}_{2}$ has increased by $12.04 \mathrm{~m}^{2} / \mathrm{g}$. The maximum adsorption capacity of $\mathrm{U}(\mathrm{VI})$ took place at $\mathrm{pH} 5.0$ for 70 minutes contact time and uranium concentration of $60 \mathrm{ppm}$. In this study, the adsorption kinetic and adsorption isotherm are pseudo second-order kinetic and Langmuir isotherm. The kinetic constant and maximum adsorption capacity of bentonite: $\mathrm{TiO}_{2}$ are $0.075 \mathrm{~g} / \mathrm{mg} \cdot \mathrm{min}$ and $5.848 \mathrm{mg} / \mathrm{g}$ respectively.
\end{abstract}

Keywords: Bentonite, $\mathrm{TiO}_{2}$, Adsorption, Uranium 


\section{ABSTRAK}

\section{ADSORPSI LIMBAH SIMULASI URANIUM MENGGUNAKAN BENTONIT:TITANIUM}

DIOKSIDA. Bentonite adalah material lempung yang mempunyai luas permukaan yang besar dan mempunyai ruang antar lapis. Ruang antar lapis pada bentonit dapat dimodifikasi menggunakan TiO2 yang mempunyai kemampuan mengadsorpsi limbah uranium. Memodifikasi bentonit dengan TiO2 akan menjadikan material tersebut mangalami peningkatan kemampuan mengadsorpsi limbah uranium. Pada penelitian ini telah dilakukan karakterisasi bentonite dan bentonit:TiO2 menggunakan instrumen FTIR, XRD dan BET untuk mengetahui gugus fungsi, basal spacing, dan luas permukaan. Selain itu juga untuk mengetahui pengaruh $\mathrm{pH}$ larutan uranium (1, 3, 5, dan 8), waktu adsorpsi (10, 20, 30, 40, 50, 60, 70, 90, dan 120 menit), dan konsentrasi larutan uranium (20, 40,60, dan 80 ppm) terhadap kapasitas adsorpsi bentonit:TiO2, serta menentukan persamaan kinetika dan isotherm adsorpsi. Hasil penelitian FTIR menunjukkan terjadi penurunan bilangan gelombang pada ikatan O-H dari molekul air yang mengindikasikan adanya TiO2 menyisip di daerah interlapis bentonit. Hasil karakterisasi XRD pada bentonit:TiO2 tidak menunjukkan puncak difraksi di bidang 001, sehingga basal spacing tidak dapat ditentukan. $\mathrm{Hal}$ ini diperkirakan karena delaminasi struktur bentonit. Delaminasi disebabkan oleh jumlah $\mathrm{TiO}_{2}$ yang terlalu banyak sehingga merusak struktur interlapis bentonit menjadi lembaran-lembaran yang tidak teratur. Struktur bentonit berbentuk lembaran akan menyebabkan jarak interlapis mengalami peningkatan yang sangat besar sehingga diperkirakan XRD sulit mendeteksi bidang 001 pada sudut 2 theta yang rendah. Luas permukaan bentonit:TiO ${ }_{2}$ mengalami kenaikan sebesar $12,04 \mathrm{~m}^{2} / \mathrm{g}$. Kapasitas adsorpsi terbaik didapatkan pada kondisi $\mathrm{pH} 5$, waktu penyerapan selama 70 menit dan konsentrasi uranium sebesar 60 ppm. Kinetika adsorpsi dan isotherm adsorpsi dalam penelitian ini adalah kinetika pseudo orde dua dan isotherm Langmuir. Konstanta kinetika dan kapasitas adsorpsi maksimum yang diperoleh sebesar 0,075 g/mg.menit dan 5,848 mg/g.

Kata kunci: Bentonit, $\mathrm{TiO}_{2}$, Adsorpsi, Uranium. 


\section{INTRODUCTIONS}

In the Mo99 radioisotope production process, $92.3 \%$ uranium enrichment of U3O8 powder target was irradiated in GA Siwabessy reactor for 96 hours at a $15 \mathrm{MW}$ reactor power [2]. Radioactive Mo99 will be separated from target (U3O8) by dissolution of U3O8 powder in concentrated nitric acid solution (HNO3) and extraction process. The extraction process has the potential to produce raffinate waste which contains uranium and fission process product.

Uranium has five oxidation states characterized by +2 to +6 , that the $U(\mathrm{IV})$ and $\mathrm{U}(\mathrm{VI})$ are the most common [2]. Uranium $\mathrm{U}(\mathrm{IV})$ does not dissolve in the water and usually gives precipitation, whereas uranium (VI) forms an ion solution [2-4]. The natural radioactive forms of uranium such as ${ }^{235} \mathrm{U}$ and ${ }^{238} \mathrm{U}$, have a half-life of $7 \times 10^{8}$ and $4.4 \mathrm{x}$ $10^{9}$ years respectively which makes them persistent in the environment and ultimately accumulates in the ecosystem in one or another form [5]. In animals and humans, uranium is adsorbed through the the digestive tract and damage the tubular cells in the kidney $[5,6]$. Uranium once released into the natural environment, it will lead to long-time potential precipitate to the soils, surface water and groundwater [7]. The World Health Organization (WHO) has classified uranium as a human cancercausing agent and its concentration in water should not exceed $15 \mu \mathrm{g} / \mathrm{L}[8,9]$. Uranium waste is a very dangerous waste, therefore it needs to be processed so that it is not polluted to humans and the environment.

The processing process that widely used in reducing uranium waste is precipitation. Precipitation method has high efficiency in waste treatment, but this method still has some disadvantages such as requires a lot of coagulant, filtration process, and produces toxic sludge [10].

Adsorption process is an alternative method of waste treatment that does not require flocculation and filtration processes, and does not produce sludge. Furthermore, adsorption method showed advantage such as easily-operability, low costs and high efficiency [11,12]. Formation of secondary waste is the main disadvantage of adsorption, such as the spent adsorbent, unusable recovered organic compounds, and organics in waste water if steam is used for regeneration. Secondary waste may require off-site treatment or specialist disposal [31]. Adsorption is a mass transfer process in which the adsorbent can selectively remove dissolved elements or molecules by capturing the molecule to its surface. Adsorption is divided into two types, namely chemical and physical adsorption. Chemical adsorption occurs due to chemical bonds between adsorbates and adsorbents such as ionic, hydrogen and covalent bonds. Physical adsorption enabled by the van der Waals forces between molecules and/or atoms on the adsorbent surface and adsorbate, whereas adsorbate resembles a condensed liquid form of the adsorptive [32]. Adsorbate approaches the surface of the adsorbent via van der Waals forces or hydrogen bonds then is followed by chemical adsorption by forming chemical bonds [13]. In physical adsorption, the adsorbed molecules can be bilayer or multilayer and the specific surface of the adsorbent depends on the area of the adsorbate molecule with a certain orientation to the surface [14]. The difference between chemical adsorption and physical adsorption are shown in Table 1.

A large number of studies have been dedicated to finding suitable and cheap adsorbents for treatment or removal of uranium from water. Bentonite consists essentially of clay minerals of the smectite (montmorillonite) group. It has a wide range of industrial applications including clarification of edible and mineral oils, paints, cosmetics, and pharmaceuticals [16]. Bentonite has interlayer cations with weak bonds to compensate the negative charge on the surface of the clay mineral [17] as illustrated in Fig 1. 
Table 1. The Differences between Chemical Adsorption and Physical Adsorption [32]

\begin{tabular}{|c|c|c|}
\hline Parameter & Chemical Adsorption & Physical Adsorption \\
\hline Type of Bonding Forces & Similar to chemical bond & Van Der Waals \\
\hline Adsorption Heat & $20-400 \mathrm{~kJ} / \mathrm{mol}$ & $10-40 \mathrm{~kJ} / \mathrm{mol}$ \\
\hline $\begin{array}{l}\text { Chemical Change of } \\
\text { Adsorptive }\end{array}$ & $\begin{array}{l}\text { Formation of a surface } \\
\text { compound }\end{array}$ & None \\
\hline Reversibility & $\begin{array}{l}\text { The process is irreversible, } \\
\text { adsorbed ones are different } \\
\text { from desorbed compounds }\end{array}$ & $\begin{array}{l}\text { Reversible. Decreasing the } \\
\text { activity of the adsorptive in the } \\
\text { fluid surrounding the surface } \\
\text { cause desorption of adsorbate } \\
\text { occurs. }\end{array}$ \\
\hline Activation Energy & $\begin{array}{l}\text { High (similar to chemical } \\
\text { reaction) }\end{array}$ & Very low (close to zero) \\
\hline Effect of Temperature & $\begin{array}{l}\text { In some extent of } \\
\text { temperature positive, so } \\
\text { called activated adsorption }\end{array}$ & Negative \\
\hline $\begin{array}{l}\text { Specificity of Adsorbate- } \\
\text { Adsorbent Interactions }\end{array}$ & High & Very Low \\
\hline Formation of Multilayers & No & $\begin{array}{l}\text { Yes. In gas phase adsorption } \\
\text { usually accompanied by } \\
\text { liquefactions in micro- and } \\
\text { mesopores. }\end{array}$ \\
\hline
\end{tabular}

The interlayer cations are easily hydrolyzable, resulting in a swelling and opening of the interlayer space, and permits to exchange with other external cations $[17,18]$. This property is responsible for great adsorbent power of bentonite, especially toward ions in solution [19]. Cationic or anionic contaminants accumulate on bentonite surfaces leading to their immobilisation through the process of ion excange, coordination, electrostatic attraction, ion-dipole interaction, $\mathrm{H}$-bonding, van der Waals interactions or hydrophobic bonding $[9,20]$. However for practical application bentonite as adsorbent need improvement in sorption capacity. Adsorption capacities of natural bentonite can be increased by pillarization process.

The clay pillaring process involves exchange of the interlayer cations with large inorganic polymeric oxy-hydroxy cationic species, which prop open the silicate layers [9]. Thus, the interlayer and specific area increase. The pillaring process is followed by calcination. The interlacation of polycation and calcination results in a stable structure with constant interlayer system to high temperature [22]. Intercalation in the interlayer of bentonite will change basal spacing as indicated by the diffraction peak shift. The bentonite diffraction peak that interpret basal spacing area is the 001 plane.

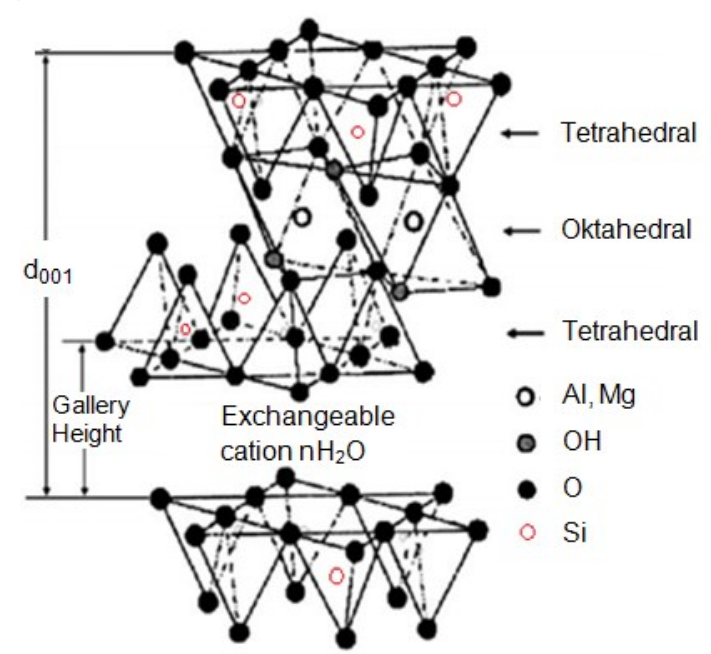

Fig. 1. Bentonite Interlayer Structure [15] 
The polycation that can be used as pillaring agent is Titanium Dioxide $\left(\mathrm{TiO}_{2}\right)$. Titanium dioxide has large specific surface area that allows combining with other materials without blocking the pores and high thermal stability [24]. Pillarization of bentonite using $\mathrm{Ti}$ cation is expected to increase basal spacing and specific surface area.

In this study, the bentonite: $\mathrm{TiO}_{2}$ was used as adsorbent for the adsorption of uranium. The purpose of this study as: (1) to know the effect of $\mathrm{TiO}_{2}$ modification to adsorption capability of Bentonite; (2) to research the effect of environmental conditions, such as $\mathrm{pH}$, contact time, and initial uranium concentration on the adsorption of uranium on bentonite: $\mathrm{TiO}_{2}$; (3) to determine the suitable adsorption kinetic and adsorption isotherm equation in describing the uranium adsorption process by bentonite: $\mathrm{TiO}_{2}$

\section{METHODOLOGY}

\section{a. Preparation of Bentonite: $\mathrm{TiO}_{2}$}

The sample was technical grade bentonite, with the major elements being Si $(52,02 \%)$, Al $(4,67 \%)$, Fe $(6,798 \%)$, $\mathrm{Ti}(0,05 \%), \mathrm{Ca}(0,327 \%), \mathrm{K} \quad(0,012 \%)$, $\mathrm{Na}(0,024 \%)$, and $\mathrm{Mg}(10,942 \%)$. Technical grade Titanium Dioxide, $\mathrm{HCl}, \mathrm{HNO}_{3}$, $\mathrm{NaOH}$, Arsenazo (III) and Uranyl Nitrate Hexahydrate were also used in this study.

Fifty grams of Bentonite mixed with $750 \mathrm{~mL}$ of $\mathrm{HCl}$ solution $2 \mathrm{M}$. Activation was carried out at $65^{\circ} \mathrm{C}$ and stirred constantly for 4 hours. Then, activated bentonite was washed by distilled water until reached $\mathrm{pH} 5$ and dried at $100^{\circ} \mathrm{C}$ for 12 hours.

Ten grams of activated bentonite were mixed with $150 \mathrm{~mL}$ of distilled water and stirred using a magnetic stirrer for 2 hours. Then, 4 grams of $\mathrm{TiO}_{2}$ powder were mixed with bentonite slurry and stirred using a magnetic stirrer for 4 hours. In the stirring process, it is expected that $\mathrm{Ti}^{4+}$ cations on $\mathrm{TiO}_{2}$ can exchange with interlayer cations in the bentonite structure. Bentonite: $\mathrm{TiO}_{2}$ is dried using an oven at $100^{\circ} \mathrm{C}$ for 12 hours. A mixture of bentonite and $\mathrm{TiO}_{2}$ is then calcined using a furnace at $500^{\circ} \mathrm{C}$ for 4 hours. Calcination aims to stabilize the intercalant and eliminate water content in the bentonite structure.

\section{b. Uranium Adsorption}

The adsorption process was performed by a batch technique at room temperature. Batch adsorption experiments were carried out by allowing an accurately weighted amount of bentonite to reach equilibrium with uranium solutions of known concentrations. Bentonite: $\mathrm{TiO}_{2}$ adsorbent had contacted with $10 \mathrm{~mL}$ of uranium solution. The mass of adsrbent used is 0.05 gram. Initial concentration of uranium were $20,40,60,80 \mathrm{mg} / \mathrm{L}$. For purpose of determining the period required to reach the adsorption equilibrium, each batch was conducted at various time intervals $(10,20$, $30,40,50,60,70,90$, and 120) min. According to previous experiment, bentonite had a maximum capacity of uranium at 120 min contact time [33]. Optimum $\mathrm{pH}$ was determined by conducting adsorption experiments on various $\mathrm{pH}(\mathrm{pH} 1,3,5$, and 7). The selection of solution $\mathrm{pH}$ value had determined base on the research that has been done by Jiaquan. In their experiment, bentonite had a minimum capacity at alkaline $\mathrm{pH}$ [30]. The $\mathrm{pH}$ was adjusted using dilute $\mathrm{HNO}_{3}$ or $\mathrm{NaOH}$ solutions.

The initial and equilibrium concentrations of uranium in clear solutions were analysed by Uv-Vis with Arzenazo method [13]. The amount of uranium adsorbent $\left(q_{t}\right.$ in $\left.\mathrm{mg} / \mathrm{g}\right)$ was determined as follows:

$q_{t}=\left(\frac{C_{t}-C_{0}}{m}\right) V$

where, $q_{t}$ is the amount of uranium ions adsorbed onto unit amount of the adsorbent $(\mathrm{mg} / \mathrm{g}), \mathrm{C}_{0}$ and $\mathrm{C}_{t}$ are the initial and final concentrations of uranium in solution $(\mathrm{mg} / \mathrm{L})$, $V$ is the volume of solution (L) and $m$ is the mass of the adsorbent $(\mathrm{g})$, respectively. 


\section{c. Adsorption Isotherm}

To obtain adsorption isotherm, a known volume $(10 \mathrm{~mL})$ of uranium solution of varying initial concentrations (20 to 80 $\mathrm{mg} / \mathrm{L})$ in beaker glass was stirred with a desired dose $(0.05 \mathrm{~g})$ of adsorbent at contact time for $70 \mathrm{~min}$, room temperature, and $\mathrm{pH}$ 5. Parameters that provide maximum adsorption capacity during adsorption experiment are used in determining the adsorption isotherm.

The experimental data for uranium adsorption by bentonite: $\mathrm{TiO}_{2}$ was fitted with the Langmuir and Freundlich isotherm. The linear form of the Langmuir isotherm model can be expressed by Eq. (2).

$$
\frac{1}{q_{e}}=\left[\frac{1}{k_{q_{0}}}\right] \frac{1}{c_{e}}+\frac{1}{q_{0}}
$$

where $\mathrm{q}_{\mathrm{e}}(\mathrm{mg} / \mathrm{g})$ is the equilibrium adsorption capacity, $\mathrm{C}_{\mathrm{e}}(\mathrm{mg} / \mathrm{L})$ is the uranium ion concentration remaining in the solution at equilibrium, $q_{0}(\mathrm{mg} / \mathrm{g})$ is the monolayer adsorption capacity of the adsorbent, and $\mathrm{k}$ $(\mathrm{L} / \mathrm{mol})$ is the Langmuir adsorption constant.

Langmuir isotherm model suggests monolayer sorption on a homogeneous surface without interaction between sorbed molecules, adsorption occurs at specific homogeneous adsorption sites within the adsorbent and intermolecular forces decrease rapidly by distance from the adsorption surface [25].

\section{d. Adsorption Kinetic}

To obtain adsorption kinetic, a known volume $(10 \mathrm{~mL})$ of uranium solution of varying contact time (10-120 min) in beaker glass was stirred with a desired dose $(0.05 \mathrm{~g})$ of adsorbent at $60 \mathrm{ppm}$ uranium concentration, room temperature, and $\mathrm{pH} 5$. The parameter used are parameters that provide maximum adsorption capacity during adsorption experiment.

The kinetics experimental data to determine the kinetics of uranium adsorption on bentonite: $\mathrm{TiO}_{2}$ were simulated using pseudo-first order (Lagergren) and pseudosecond order (Ho). The linear form of pseudo-first order kinetic model can be represented by following equation :

$\ln \left(q_{e}-q_{t}\right)=\ln _{q_{e}}-\frac{k 1}{2,303} t$

Where k1 represents the pseudo-first order adsorption rate constant (L/min), qe $(\mathrm{mg} / \mathrm{g}$ ) is the adsorption capacity of uranium at equilibrium, $t$ is the contact time ( $\mathrm{min}$ ) and qt is the amount of adsorbed uranium at time $t$ $(\mathrm{mg} / \mathrm{g})$. The linear pseudo-second order model can be represented as Eq. (4)

$$
\frac{t}{q_{t}}=\frac{1}{k_{2} q_{e}^{2}}+\frac{1}{q_{t}} t
$$

where $k_{2}$ is the pseudo-second order adsorption rate constant ( $\mathrm{g} / \mathrm{mg} \cdot \mathrm{min})$.

Freundlich assumes that adsorption occurs on a heterogeneous surface $[9,26]$. The freundlich isotherm model can be expressed by Eq. (5).

$$
\ln _{q e}=\ln _{k f}+n \ln C e
$$

where $\mathrm{kf}(\mathrm{mg} / \mathrm{g})\left((\mathrm{mg} / \mathrm{L})^{\mathrm{n}}\right)^{-1}$ is the Freundlich constant, and $\mathrm{n}$ is an empirical factor relating to the adsorption intensity.

\section{RESULTS AND DISCUSSION}

\section{a. Characterisation of Bentonite: $\mathrm{TiO}_{2}$}

1. FTIR

The FTIR spectra of bentonite: $\mathrm{TiO}_{2}$ differed from that of raw bentonite. The broad band on 3456.51 and $3439.27 \mathrm{~cm}^{-1}$ was due to the interlayer $\mathrm{H}$-bonded $\mathrm{O}-\mathrm{H}$ stretching. The band at 1640.84 and $1636.22 \mathrm{~cm}^{-1}$ represented the $\mathrm{H}-\mathrm{O}-\mathrm{H}$ bending vibration of water. This shows that the $\mathrm{H}-\mathrm{O}-\mathrm{H}$ bending of bentonite: $\mathrm{TiO}_{2}$ was decreased. We suggest that water molecules in the bentonite: $\mathrm{TiO}_{2}$ structure after being added by titanium dioxide have decreased due to drying process at high 
temperature. The band of 1044.23 and $1050.55 \mathrm{~cm}^{-1}$ might be attributed to the siloxane (Si-O-Si) group stretching. The band at $792.87 \mathrm{~cm}^{-1}$ might correspond to the $\mathrm{O}-\mathrm{Si}-\mathrm{O}$ bonds. The band at 472.08 and 470.92 represented the Si-O bending.

The FTIR curve of bentonite and bentonite: $\mathrm{TiO}_{2}$ is illustrated in Fig 3 and Fig 4 , respectively. It can be seen that the band of bentonite at $3456.51 \mathrm{~cm}^{-1}$ (Fig 3) has decreased towards a shorter band, which is $3439.27 \mathrm{~cm}^{-1}$ (Fig 4) indicates a decrease in
$\mathrm{O}-\mathrm{H}$ bond. This is expected to occur due to the addition of $\mathrm{TiO}_{2}$. We suggest that the bond between $\mathrm{Ti}$ cations and $\mathrm{TiO}_{2}$ with oxygen (O) from $\mathrm{O}-\mathrm{H}$ occurs in the bentonite structure so that the $\mathrm{O}-\mathrm{H}$ bond decreases. The presense of $\mathrm{TiO}_{2}$ in bentonite structure cause increasing the adsorption capacity of bentonite. According to previous research journal, the $\mathrm{UO}_{2}{ }^{2+}$ ion is specifically adsorbed on titanium dioxide [33]. The adsorption reaction is explain by Eq.6.

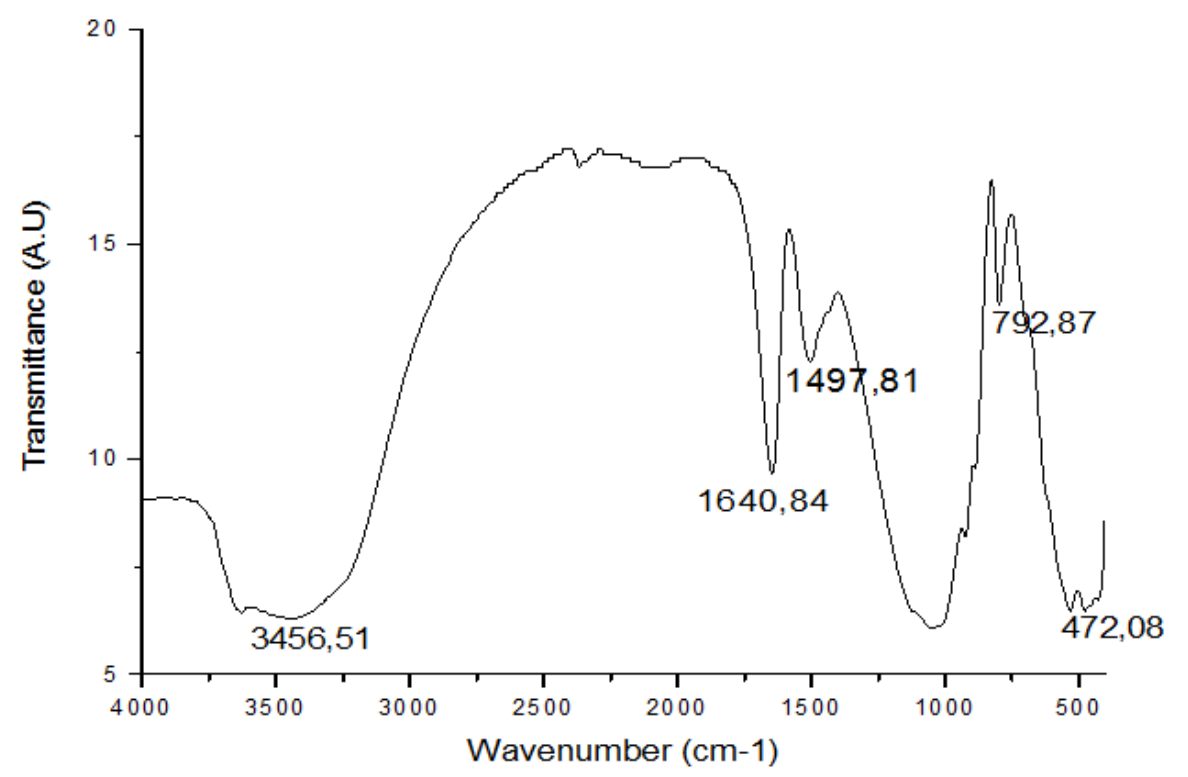

Fig. 3. Natural Bentonite FTIR Curve

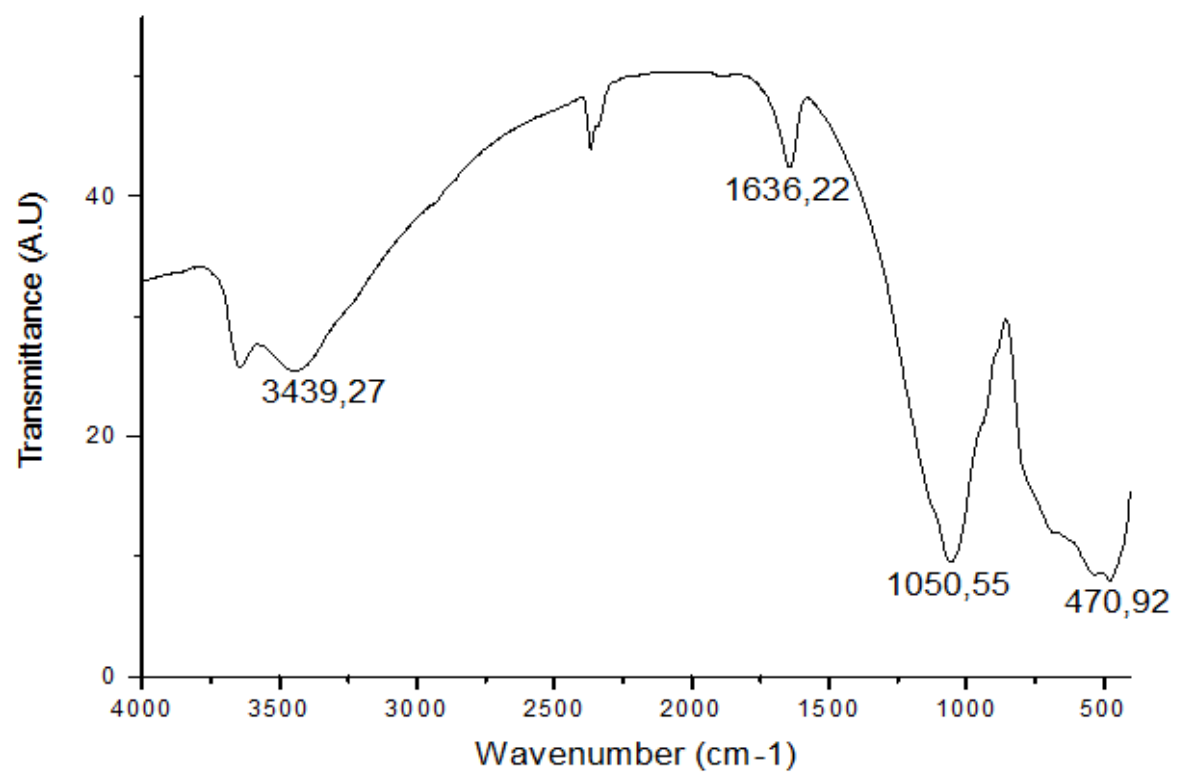

Fig. 4. Bentonite: $\mathrm{TiO}_{2}$ FTIR Curve 


$$
\mathrm{TiOH}+\mathrm{UO}_{2}^{2+}+\mathrm{X}^{-} \longrightarrow(\mathrm{TiO})_{2} \mathrm{UO}_{2}+\mathrm{X}^{-}+\mathrm{H}^{+}
$$

\section{XRD Analysis}

The XRD patterns of raw bentonite and bentonite: $\mathrm{TiO}_{2}$ were shown in Fig 5. The basal spacing for raw bentonite was, representing the typical XRD pattern of bentonite with the do01 plane presenting in $12,27 \AA$ peak at about $7,21^{\circ}$. After modification with $\mathrm{TiO}_{2}$, there is no characteristic peak in the 001 plane, so the basal spacing of bentonite: $\mathrm{TiO}_{2}$ can not be calculated. We suggest that the loss of 001 plane of bentonite: $\mathrm{TiO}_{2}$ occured due to delamination [27].

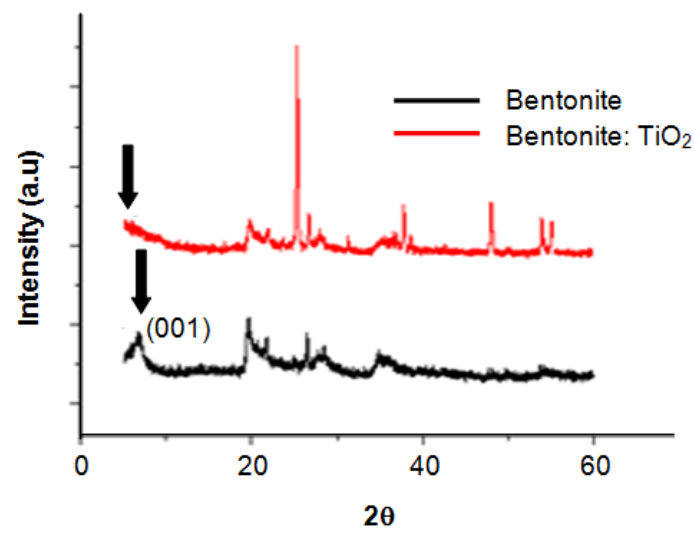

Fig. 2. Bentonite and Bentonite: $\mathrm{TiO}_{2}$ Diffractogram

Table. 2 BET Analysis of Bentonite and Bentonite: $\mathrm{TiO}_{2}$

\begin{tabular}{lcc}
\hline & Bentonite & Bentonite: $\mathrm{TiO}_{2}$ \\
\hline Specific Surface Area $\left(\mathrm{m}^{2} / \mathrm{g}\right)$ & 68.23 & 80.27 \\
Pore Diameter $(\AA)$ & 27.02 & 17.11 \\
\hline
\end{tabular}

\section{b. Adsorption Study}

1. Effect of $\mathrm{pH}$

The solution of $\mathrm{pH}$ can affect the charge of adsorbent and adsorbate, then it affects the electrostatic interaction between adsorbent and adsorbate [28]. The strong interactions such as electrostatic attraction or complexation are exist between adsorbent and adsorbate only in suitable $\mathrm{pH}$ value. In this study, the effect of $\mathrm{pH}$ on uranium adsorption on bentonite: $\mathrm{TiO}_{2}$ was investigated in the $\mathrm{pH}$ range of $1.0-8.0$. As
The occurence of delamination causes the bentonite interlayer structure was delaminated to become sheets and hence, the basal spacing becomes very large. Basal spacing is inversely proportional to the value of 2 theta angle. Basal spacing is very large due to the irregularity of the bentonite structure after delamination causes the smaller 2 theta angle. The position of 2 theta angles that are too small are estimated to be difficult to detect using an XRD instrument.

\section{BET}

Surface area of bentonite and bentonite: $\mathrm{TiO}_{2}$ is shown in Table 2. The BET characterization results are related to the $X R D$ characterization results in the previous discussion. During the delamination process, the bentonite structure changes into smaller sheets and results in a surface area of bentonite: $\mathrm{TiO}_{2}$ increases.

Similar results were also obtained in the research conducted by Carriazo [27]. Carriazo obtained the surface area of $\mathrm{TiO}_{2}-$ laminated bentonite which increased from $42.8 \mathrm{~m}^{2} / \mathrm{g}$ to $86.4 \mathrm{~m}^{2} / \mathrm{g}$. 
surpasses that of the uranium ions at $\mathrm{pH} 1$ and $\mathrm{pH} \mathrm{3}$, and hence, they compete with uranium ions for the active sites on the surface of bentonite: $\mathrm{TiO}_{2}$. At $\mathrm{pH}$, hydrolysis of uranium ions occurs, producing complexes such as $\mathrm{UO}_{2}(\mathrm{OH})_{3}{ }^{-}, \mathrm{UO}_{2}(\mathrm{OH})_{4}{ }^{2-}$, and $\left(\mathrm{UO}_{2}\right)_{3}(\mathrm{OH})_{7}^{-}$[31]. Negatively charged species will cause the attractiveness of the adsorbate to become low and limit the amount of adsorbate absorbed by bentonite: $\mathrm{TiO}_{2}$.

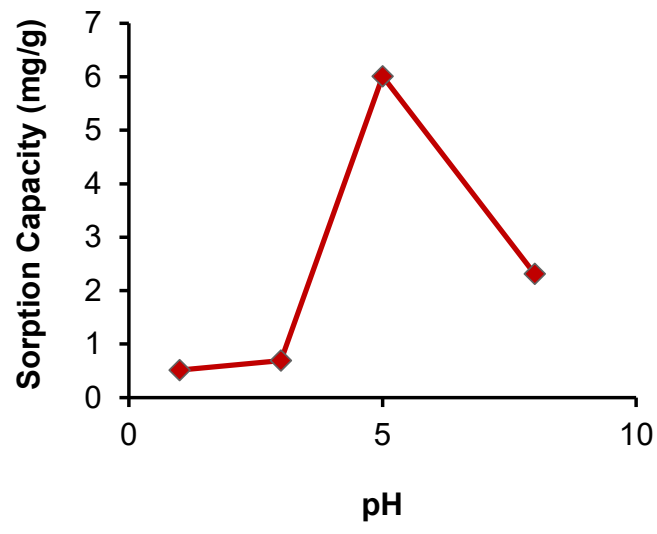

Fig. 3 pH vs Sorption Capacity
2. Effect of Initial Concentration and Contact Time

The influence of contact time and initial uranium concentration on the sorption capacity of uranium (qt) is illustrated in Fig 7 . At 40,60 and $80 \mathrm{ppm}$ uranium concentrations, the qt value relatively increases with increasing time of absorption. At $20 \mathrm{ppm}$ uranium concentration, the qt value is relatively constant. This is due to concentration of uranium is relatively small and hence, there is no significant increase in qt value in each contact time. In this study, uranium concentrations of 60 and $80 \mathrm{ppm}$ will be used as the optimum concentration adsorbed by bentonite: $\mathrm{TiO}_{2}$. A concentration of $60 \mathrm{ppm}$ will be compared with a concentration of $80 \mathrm{ppm}$ to determine the difference in qt results obtained at each time of absorption. Determination of optimum concentration was determined using ANOVA analysis.

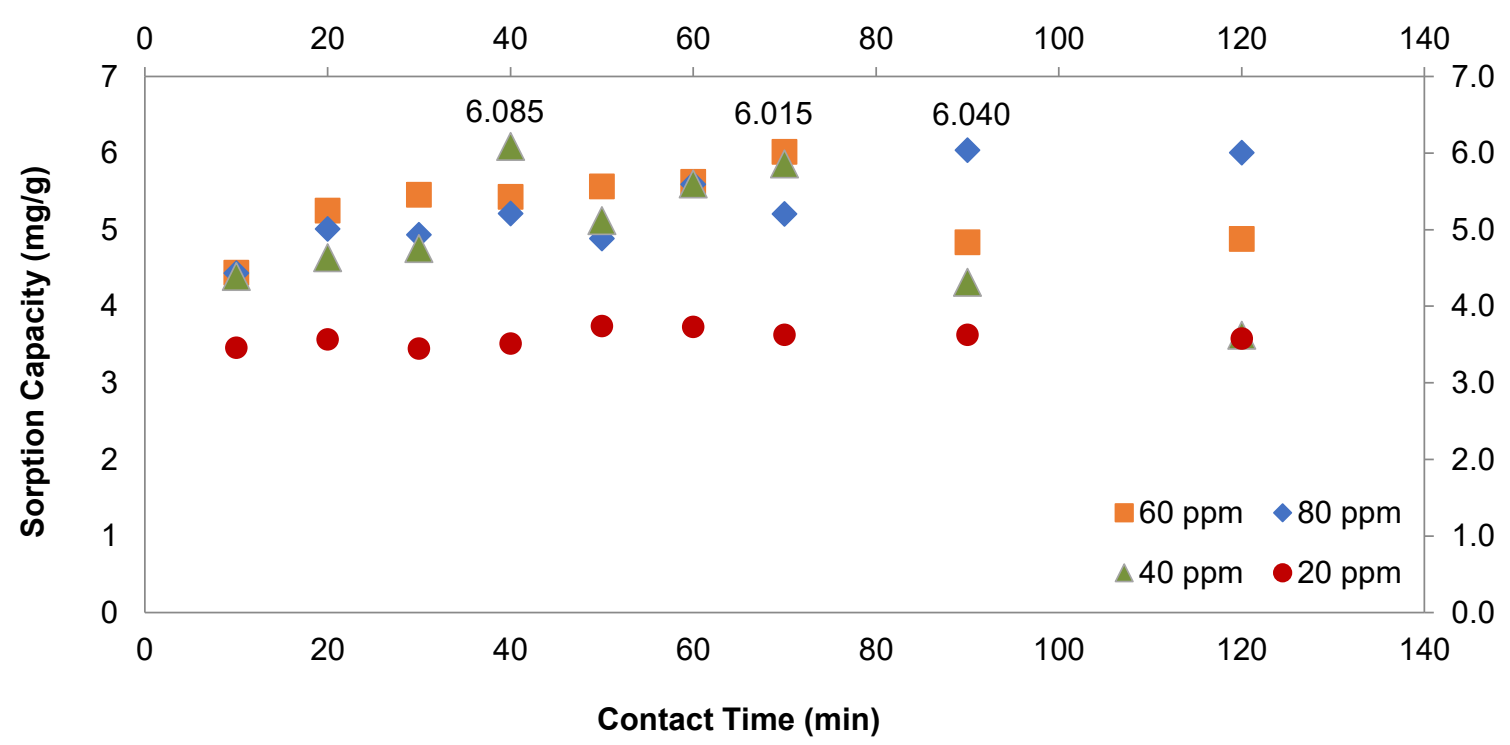

Fig. 4 Contact Time vs Sorption Capacity

$F$ value is smaller than $F$ crit value and consequently, there is no significant effect by increasing uranium concentration from $60 \mathrm{ppm}$ to $80 \mathrm{ppm}$ to te values of sorption capacity. The average distribution of qt values at 60 and $80 \mathrm{ppm}$ were not significantly different. At concentration uranium of $60 \mathrm{ppm}$, maximum sorption capacity is obtained at 70 minutes of contact time, while at concentration of $80 \mathrm{ppm}$, the maximum adsorption capacity was generated at 90 minutes contact time. The shorter contact time is better because it will be more profitable and economical. 
Therefore, 70 minutes and $60 \mathrm{ppm}$ were chosen as optimum contact time and uranium concentration for uranium adsorption by bentonite: $\mathrm{TiO}_{2}$, respectively.

\section{Adsorption Kinetic}

Kinetic models were applied to the experimental data in order to understand the potential rate controlling steps and mechanism of reaction. The pseudo firstorder and pseudo second-order kinetic models were applied to describe the kinetic characteristic of uranium ions adsorption by bentonite: $\mathrm{TiO}_{2}$.
The Pseudo-first order constant ( $\mathrm{k} 1)$ could be obtained by plotting log (qe-qt) versus $t$. The pseudo-second order constant (k2) can be determined from the slope of plot $t / q t$ versus $t$. The kinetic parameter with the corresponding coefficient of determination $\left(R^{2}\right)$ are shown in Table 3 . The coefficient of determination of the pseudo second-order kinetic model is higher than that of the pseudo first order kinetic model. Therefore, the pseudo second-order kinetic model can be adopted to explain the sorption process of uranium onto bentonite: $\mathrm{TiO}_{2}$.

Table. 3. Adsorption Kinetic Parameters

\begin{tabular}{llll}
\hline No & Adsorption Kinetic & $\mathrm{K}$ & $\mathrm{R}^{2}$ \\
\hline 1 & Pseudo-First Order & $0.004 \mathrm{~min}^{-1}$ & 0.054 \\
2 & Pseudo-Second Order & $0.075 \mathrm{~g} / \mathrm{mg} \cdot \mathrm{min}$ & 0.992 \\
\hline
\end{tabular}

\section{Adsorption Isotherm}

Isotherm adsorption is a mathematical model that describes the distribution of adsorbate in solution and adsorbent using assumption in the form of heterogeneity and homogeneity of the adsorption prosess, and interactions between adsorbate and adsorbent [30]. The adsorption isotherm used to describe the mechanism of uranium adsorption by bentonite: $\mathrm{TiO}_{2}$ were Langmuir isotherm and Freundlich isotherm.

The corresponding coefficient of determination $\left(R^{2}\right)$ on Freundlich and Langmuir isotherm are shown in Table 4.
The type of adsorption isotherm that has the $\mathrm{R}^{2}$ value closest to 1 is the langmuir isotherm. Therefore, uranium adsorption process on the surface of bentonite: $\mathrm{TiO}_{2}$ occurs homogeneously to form one layer and there is no interaction between adsorbates. Maximum adsorption capacity of bentonite: $\mathrm{TiO}_{2}$ to form one layer in the adsorption process of $5.848 \mathrm{mg} / \mathrm{g}$.

Table. 4. Adsorption Isotherm Parameters

\begin{tabular}{lll}
\hline No & Adsorption Isotherm & $\mathrm{R}^{2}$ \\
\hline 1 & Freundlich Isotherm & 0.768 \\
2 & Langmuir Isotherm & 0.954 \\
\hline
\end{tabular}

Table. 5. Uranium Sorption Capacity by Different Adsorbent

\begin{tabular}{ccc}
\hline No & Adsorbent & Sorption Capacity $(\mathrm{mg} / \mathrm{g})$ \\
\hline 1 & Bentonite: $\mathrm{TiO}_{2}$ & 5,848 \\
2 & Natural Bentonite (In this study) & 2,355 \\
3 & Hematite [27] & 3,540 \\
4 & Bentonite [30] & 4,150 \\
5 & Ferric Oxide-modified Zeolite [21] & 0,240 \\
\hline
\end{tabular}

The adsorption capacity of bentonite: $\mathrm{TiO}_{2}$ with several adsorbents is shown in the Table 5 . The capacity of uranium adsorption by bentonite: $\mathrm{TiO}_{2}$ is greater than some types of adsorbents and bentonite without $\mathrm{TiO}_{2}$. Based on the results obtained, the addition of $\mathrm{TiO}_{2}$ can increase the capacity of natural bentonite. 


\section{CONCLUSIONS}

A natural bentonite and bentonite: $\mathrm{TiO}_{2}$ sample were characterized by using FTIR, XRD, and BET determined its functional group, basal spacing, and specific surface area, and investigate the adsorption of bentonite: $\mathrm{TiO}_{2}$ in various environmental factors such as $\mathrm{pH}$, contact time, and initial uranium concentration. The adsorption of uranium on bentonite obviously depends on $\mathrm{pH}$ values. The higher the concentration of uranium solution and the contact time, the adsorption capacity of uranium by bentonite $\mathrm{TiO}_{2}$ is relatively increased before reaching equilibrium conditions. In this study, the optimum uranium concentration and contact time were taken at $60 \mathrm{ppm}$ and 70 minutes, respectively. The surface area and adsorption capacity of uranium by bentonite increased after delamination occurs. The surface area of bentonite before and after $\mathrm{TiO}_{2}$ added were $68.23 \mathrm{~m}^{2} / \mathrm{g}$ and $80.27 \mathrm{~m}^{2} / \mathrm{g}$ Adsorption capacity has increased by 3.493 $\mathrm{mg} / \mathrm{g}$. The kinetic data signified that sorption of uranium onto bentonite: $\mathrm{TiO}_{2}$ followed the pseudo second-order kinetic model. Sorption of uranium onto bentonite: $\mathrm{TiO}_{2}$ was best described by the Langmuir isotherm model. The reaction kinetics constant and adsorption capacity obtained were 0.075 $\mathrm{g} / \mathrm{mg}$.min and $5.848 \mathrm{mg} / \mathrm{g}$, respectively. The adsorption capacities of uranium onto bentonite: $\mathrm{TiO}_{2}$ were found to be higher than for natural bentonite.

\section{REFERENCES}

[1] Aisyah, H. Martono, Wati, "Pengolahan limbah produksi radioisotop menggunakan resin penukar ion", Jurnal Forum Nuklir, vol.4, no.1, hal. 1-12, 2010.

[2] S. Abdi, M. Nasiri, A. Mesbahi and M.H Khani., "Investigation of uranium (VI) adsorption by polypyrrole," Journal of Hazardous Materials, 2017.

[3] U. Gerber, et al., "Combined use of flow cytometry and microscopy to study the interactions between the gram-negative beta proteobacterium acidovorax facilis and uranium (VI)," Journal of Hazardous Materials, vol. 317, pp.127-134, 2016.

[4] F. Li, et al., "Rapid removal of uranium from aqueous solutions using magnetic $\mathrm{Fe}_{3} \mathrm{O}_{4} @ \mathrm{SiO}_{2}$ composite particles," Journal of Environmental Radioactivity, vol. 106, pp. 40-46, 2012.

[5] S. Rajendran, R. Govindarajan, P. Mridula, R. Karuppuli, T. Palanisami, N. Ravi, M. Mallacarapu., "Challenge and complexities in remediation of uranium contaminated soils: A review", Journal of Environmental Radioactivity, 2018.

[6] R. Konietzka, "Gastrointestinal absorption of uranium compounds: A review", Regulatory Toxicoogy and Pharmacology, vol. 71 , no. 125, pp.191-199, 2015.

[7] Liu, Peng., Wu, Hanyu., Yuan, Ni., Liu, Yanqi., Pan, Duoqiang., Wu, Wangsuo, "Removal of $\mathrm{U}(\mathrm{VI})$ from aqueous solution using synthesized bzeolite and its ethylenediamine derivative," Journal of Molecular Liquids, vol. 234, pp. 40-48, 2017.

[8] WHO, World Health Organization., "Uranium in drinking water quality, background document fr development of WHO guidelines for drinking water quality", 2012.

[9] P. M. Nekhunguni, N. T. Tavengwa, $\mathrm{H}$. Tutu, "Sorption of uranium (VI) onto hydrous ferric oxide-modified zeolite: Assessment of the effect of $\mathrm{pH}$, contact time, temperature, selected cations and anions on sorbent interactions", Journal of Environmental Management, vol. 204, pp. 571-582, 2017.

[10] A. Kausar, et al, "Dyes Adsorption Using Clay and Modified Clay: A Review", Journal of Molecular Liquids, vol. 256, pp. 395-407, 2018. 
[11] M. F. Keling, O. F. V. Fergenblatt, M. N. Ajis, M. S. Shuib, A. D. M Nadzri, "The impact of east asia's nuclear energy development program on southeast asia countries," Journal of Politics and Law, vol. 3, no.2, pp. 176183, 2010.

[12] M. M. Zareh, A. Aldaher, A. E. M. Hussein, M. G Mahfouz, M. Soliman, "Uranium adsorption from a liquid waste using thermally and chemically modified bentonite", Journal of Radioanalytical and Nuclear Chemistry, vol. 295, no. 2, pp. 13571159, 2012.

[13] R. Langenati, "Pengaruh jenis adsorben dan konsentrasi uranium terhadap pemungutan uranium dari larutan uranil nitrat," Jurnal Teknik Bahan Nuklir, vol. 8, no. 2, hal. 95104, 2012.

[14] Bergaya, F., G. Lagaly., M. Vayer., Developments in clay science," Cation and Anion Exchange, 2nd ed, Elsevier Ltd.

[15] R. L. Anderson, et al, "Clay swelling A challenge in the oilfield", EarthScience Reviews, vol. 98, no. 3-4, pp. 201-216, 2010.

[16] G. Christidis, "Physical and chemical properties of some bentonite deposits of kimolos island, Greece," Applied Clay Science, vol.13, pp. 79-98, 1998.

[17] K. Sapag, S. Mendioroz, "Proper stability in porous media based in a natural clay", Granular Matter, vol. 3, no. 1-2, pp. 131-135, 2001.

[18] M. E. R. Jalil, S. Vieira Rodrigo, A. Diana, B. Miria, S, Karim., "Improvement in the adsorption of thiabendazole by using aluminium pillared clays", Applied Clay Science, vol. 71, pp. 55-63, 2013.

[19] I. Belbachir, B. Makhoukhi, "Adsorption of bezathren dyes onto sodic bentonite from aqueous solutions," Journal of the Taiwan
Institute of Chemical Engineers, vol. 75, pp. 1-7, 2017.

[20] K. G. Bhattacharyya, S. S. Gupta, "Adsorption of a few heavy metals on natural and modified kaolinite and montmorillonite: A Review," Advances in Colloid and Interface Science, vol. 140, pp.114-131, 2008.

[21] K. Bahranowski, et al., "[Ti-Zr]-pillared montmorilonite - A new quality with respect to Ti- and Zr-pillared clays," Microporous and Mesoporous Materials, vol. 202, pp. 155-164, 2015.

[22] B. González-Rodríguez, et al., "Structural, textural and acidic properties of $\mathrm{Cu}$-, $\mathrm{Fe}$ - and $\mathrm{Cr}$-doped Ti-pillared montmorillonites," Applied Clay Science, vol.118, pp. 124-30, 2015.

[23] M. A. Vicente, A. Gil, F. Bergaya, Developments in clay science," Pillared Clays and Clay Minerals, 2nd ed, Elsevier Ltd, 2013.

[24] S. Zuo, et al., "Study on the preparation and characterization of a titanium-pillared clay-supported $\mathrm{Cr} \mathrm{Ce}$ catalyst and its application to the degradation of a low concentration of chlorobenzene." Applied Clay Science, vol. 105-106, pp.118-136, 2015.

[25] S. M. Yakout, S. S. Metwally, T. ElZakla, "Uranium sorption onto activated carbon prepared from rice straw: Competition with humic acid," Applied Surface Science, vol. 280, pp. 745-750, 2013.

[26] M. Solgy, M. Taghizadeh, D. Ghoddocynejad., "Adsorption of uranium (VI) from sulphate solutions using Amberlite IRA-402 resin: Equilibrium, kinetics, and thermodynamics study," Annals of Nuclear Energy, vol. 75, pp. 132-138, 2015.

[27] J. G. Carriazo, M. Morreno-Forero, R. A. Molina, S. Moreno, "Incorporation 
of titanium and titanium-iron species inside a smectite-type mineral for photocatalysis," Applied Clay Science, vol. 50, no. 3, pp. 401-408, 2010.

[28] J. Wang, et al., "Adsorption of $\mathrm{U}(\mathrm{VI})$ on bentonite in simulation environmental conditions," Journal of Molecular Liquids, vol. 242, pp. 678684, 2017.

[29] A. Nilchi, T. S. Dehaghan, S. R. Garmarodi, "Kinetics, isotherm and thermodynamics for uranium and thorium ions adsorption from aqueous solutions by crystalline tin oxide nanoparticles," Desalination, vol. 321, pp. 67-71, 2013.

[30] P. Sjoholm, Petri., D. B. Ingham, M. Lehtimaki, L. Perttu-Roiha, $\mathrm{H}$. Goodfellow, H. Torvela, Industrial ventilation design guidebook: Gas cleaning technology, Chapter 13, pp. 1197-1316, 2001.

[31] M. Kralik, "Adsorption, chemisorption, and catalysis review," Chemical Papers, vol. 68 , no. 12 , pp. $1625-$ 1638, 2014.

[32] N. Jaffrezic-Renault, H. AndradePoirier, D. H. Trang, "Models for The Adsorption of Uranium on Titanium Dioxide," Journal of Chromatography, vol. 201, pp. 187 - 192, 1980.

[33] W. M, Youssef, "Uranium adsorption from aqueous solution using sodium bentonite activated clay," Journal of Chemical Engineering \& Process Technology, vol. 8 , no. 4, p. 384 , 2017. 